\title{
MOBILE CONCEPTS IN A MOBILE ENVIRONMENT: HISTORICAL TERMS IN LSP LEXICOGRAPHY
}

DOI: http://dx.doi.org/10.17159/2223-0386/2018/n18a2

Michele F van der Merwe

Karen Horn

Stellenbosch University

Stellenbosch University

michelevdm@sun.ac.za

karenhorn@sun.ac.za

\section{Abstract}

Historical terms have a tendency to be "mobile" in terms of geographical space and historical time. The presentation of historical terms by means of a mobile dictionary enabling university students to access such terms by means of a smartphone, tablet or laptop adds to the dimension of mobility. The article describes the continuous change in meaning of historical concepts over time and space with reference to democracy and nationalism, which are known as substantive concepts. An analysis of the emergence and development of these concepts within different historical contexts indicates the extent to which static definitions are inadequate with regard to fostering historical understanding.

A tendency to continuous change in the meaning of the above-mentioned terms has important implications for the compilation of a Language for Specific Purposes (LSP) dictionary of historical terms at university level, and for the consequences thereof for mobile LSP lexicography. The LSP dictionary called MobiLex has a pedagogical purpose and changes in the design and features of the dictionary to enhance teaching and learning of historical terms have pedagogical consequences regarding the learning of such terms.

In an ever-changing environment, adaptions to mobile lexicography would be possible with the advancement of technology. Trends and development in technology offer the possibility of changing the face of lexicographical support in a mobile environment, motivated from a pedagogical theoretical point of view.

Keywords: Historical terms; LSP lexicography; Mobile dictionary; Substantive concepts; Nationalism; Democracy.

\section{Introduction}

This article seeks to find an answer to dealing with the mobility of historical terms. It is the result of an interdisciplinary collaboration between the humanities and education exploring collaboration between lexicography, specifically metalexicography concerning Language for Specific Purposes (LSP) dictionaries, and history teaching, in particular the teaching of historical terms at tertiary level. The ever-changing meaning of some historical terms is 
problematised.

The debate on the role of language in History education is an ongoing one. Caroline Coffin sees the "linguistically demanding nature of history" as one of the main reasons for the declining number of History learners (Coffin, 2006:1). She also believes History does not offer understandings of the past in a stable or fixed manner (Coffin, 2006:3). Historians seek to create knowledge about the past, relying on their research methods to present their readers with a version of the past which they believe to be reliable. However, as they compile their analyses and narratives, they select and discard sources of information on the basis of the thesis or research question. As such, readers and students are left with a variety of interpretations of the past (Donnelly $\&$ Norton, 2011:54-55).

While historians understand and apply the multiple understandings in their research, student teachers who specialise in history educationdo not seek to fill the knowledge gaps of the past. Their aim is to find ways in which to explain past events to learners, to help them understand historical significance, context and relevance. As such, there is a need for student teachers to understand the procedural concepts of history, as well as the substantive concepts. In addition, it is also crucial that student teachers recognise the malleable nature of substantive concepts. It is here that mobile lexicography may function as an educational aid.

The background and research problem with regard to the inclusion of historical concepts in mobile lexicography is posed in the article; the problem encountered with mobility of historical concepts is analysed; possible online lexicographical resources for solutions are investigated; and adaptions to mobile LSP lexicography are suggested within a pedagogical framework for the implementation of technology in teaching.

\section{Background and research problem}

According to Alberts (2017:2), LSP signifies the language used by expert communities with a greater or smaller range of terminology and domainspecific or subject-specific linguistic conventions. LSP deviates to varying extents from language for general purposes (LGP) (i.e. the language used largely in everyday communication by any language community). LGPs therefore are the languages of individual language communities, whereas LSPs are the specialised languages used by expert communities within a broader language community. 
MobiLex (http://www0.sun.ac.za/mobilex), a trilingual LSP dictionary, is currently being developed by University X. As MobiLex is designed as a mobile dictionary to be used on a smartphone, tablet or laptop, definitions are shorter and mostly restricted to being viewed on the small screen of a phone with the result that definitions of terms and concepts are quite brief and concise. Current definitions of the historical concepts democracy and nationalism in MobiLex are adequate for users, namely first-year students in education, to understand the meaning of the concepts, but they do not give an account of the development of concepts, as it is crucial for teaching of history at university level.

The main research question is how the lexicographer would make provision for the continuous development and change of historical concepts in a mobile LSP dictionary.

Sub questions to be answered in the article:

- What is the ever-changing nature of some historical concepts?

- Which online lexicographical resources could be consulted in the search for terms on History?

- How could encyclopaedic information be used in collaboration with technology in a mobile LSP dictionary in a pedagogically-motivated model for teaching?

The research methodology employed for this article comprised a detailed analysis of a single problem encountered during the compilation of historical concepts for MobiLex. A detailed analysis of concepts would be an example of a small-scale study (Punch \& Oancea, 2014:47) with the advantage that researchers could go into considerable depth with the study. With a smallscale study, researchers could concentrate in depth on critical or challenging situations. The challenge to researchers described in the article pertained to the training, in particular the concept and language support via mobile technology of student teachers in History Education at University X and the problem of mobility of historical concepts encountered by the researchers in the compilation of MobiLex. An analysis of the problem regarding the mobility and flexibility of historical concepts was done, with reference to current online lexicographical resources, as well as the possibility of accommodating concepts in a meaningful manner. 


\section{Analyses of problem}

It is crucial for student teachers to understand both procedural and substantive knowledge of history to be able to think historically. In the National Curriculum and Assessment Policy Statements (CAPS) procedural knowledge is stated as "concepts" and aligned with the "skills" that learners are to acquire in the history classroom. For instance, the concepts include "multi-perspectivity", which is described in the skills table as learners' ability to "explain why there are different interpretations of historical events and peoples' actions" (CAPS, 2011:9-10). Other concepts include "cause and effect", "change and continuity", "time and chronology", and "historical sources and evidence" (CAPS, 2011:10). This procedural knowledge, according to Stéphane Lévesque (2008:29-30), is crucial for the construction of a coherent and nuanced argument about the past.

Substantive knowledge, on the other hand, is the content of history, or as David Neumann (2012:387) puts it, "substantive concepts provide the categories for the 'stuff of history". Compared to procedural concepts, substantive concepts have received relatively little research attention (Neumann, 2012:387). CAPS does not provide a definitive list of substantive concepts, but an examination of the content section provides a list that includes concepts such as "revolution", "colonialism", "communism", "capitalism", "nationalism", and "democracy". While there are countless more examples of substantive concepts within CAPS, the focus in this case falls on nationalism and democracy to illustrate the challenges and possible opportunities that an LSP dictionary such as MobiLex may offer. Meaningful historical knowledge depends on deep understandings of substantive terms such as these. Merely memorising set definitions do not allow for critical analysis, and as such students' knowledge remain superficial, or worse, it may lead to misunderstandings and misconceptions which may render the subject of history irrelevant.

Many students who aim to become history teachers often enter teaching programmes from a variety of educational contexts. Some complete a degree before completing a one-year post-graduate certificate of education, while others enter education faculties upon leaving secondary schools. It is these students, who often have one-dimensional understandings of substantive historical terms as many may not recognise the nuanced and complex nature of history, nor of the subject's substantive concepts. This is especially the case when students enter teaching programmes without any prior tertiary History education. More often than not, these student teachers have yet to develop the skill to employ 
systemic functional linguistics (SFL) which allows for the use of language as a tool that makes knowledge socially and educationally useful; a crucial aspect of understanding and communicating the meaning of substantive concepts across different historical contexts (Coffin, 2006:11-12). As such, novice student teachers may rely on one conclusive definition of a concept such as democracy or nationalism. From a historiographical point of view, however, both of these terms are greatly flexible, with different historical periods or geographical areas determining the exact nature and meaning of each concept.

In his book Nations and Nationalism since 1780, Eric Hobsbawn (2012:9) makes the point that concepts are "socially, historically and locally rooted, and must be explained in terms of these realities". Gavin Williams (2003:339) similarly states that "political concepts such as democracy are "essentially contested" [and the meaning] will depend on the ways in which they are used in specific historical contexts".

The CAPS document does not offer explanations on the shifting nature of substantive concepts, but it assumes instead that teachers, and student teachers, understand how historical context may alter, or formulate, definitions. With regard to the concept of nationalism, CAPS alludes to the nuances of the term, stating that the "concept of nationalism needs to be studied as a phenomenon that changed form during the Second World War, but has a long history" (2011:22). With regard to the concept of democracy, however, no such indications are presented in the CAPS documents, yet there are references to democracy across different historical periods and geographical areas, including the "foundations of modern democracy" during the French Revolution of 1789 to 1799 , the emergence of democracy in Africa during the 1960s and 1970s, and the democratic process in South Africa, among others $(2011: 15,27,30)$. As such, CAPS offers no clear explanation of substantive concepts and the way in which these concepts may change over time and place. For student teachers with an inadequate grasp of the nature of history, the guidance provided by CAPS with regard to the interpretation of substantive concepts is insufficient and inadequate.

It is clear, therefore, that there is practical value for mobile lexicography in the classroom, but the definitions that an aid such as MobiLex offers must accommodate the changing nature of the concepts. In order to illustrate the requirement of adaptability of a lexicographic teaching aid, the current MobiLex definitions for democracy and nationalism are analysed within a historical context.

\section{Democracy}


At present, the MobiLex definition for democracy is as follows:

A political system in which sovereign power resides in the people (;) who directly, as in ancient Athens, or indirectly, through representatives, decide the way they are governed. The term Democracy in its modern sense came into use in the course of the nineteenth century to describe a system of representative government in which the representatives are chosen by free competitive elections (MobiLex, http:// www0.sun.ac.za/mobilex).

While this definition takes into account some aspects of Hobsbawn's notion of concepts, that of the social, historical and geographical aspects that determine the exact meaning of the concept, it does not allow for Williams' idea of the contested nature of such concepts.

The MobiLex definition of democracy refers to a system that evolved in ancient Athens, yet the exact nature, and in some cases the very existence, of a democratic system is a matter of intense debate among specialist academics of the Classical World (Connor, 2018:165-175). The ongoing scholarly discussions create the distinct impression that, although the Athenian political system may have given birth the concept, democracy evolved to such an extent that the original ancient form had become all but unrecognisable by the nineteenth century when democracy came to be a representative form of government.

How changeable these concepts are becomes clear through analysing the way in which scholars seek to define the concepts of democracy and nationalism when writing about specific geographical areas, historical periods or social constructs. For instance, in writing about the emergence of democracy in Africa during the 1960s when many African states gained independence from their erstwhile colonial rulers, Maxwell Owusu (1992:370) makes the point that the manner in which the states gained freedom, and the purpose of adopting a democratic system, determined the state's unique democratic nature. In other words, the method of transition from colony to independent state defined that state's unique form of democracy. Democracy in Ghana, the first of the African colonies to gain independence thanks to Kwame Nkrumah's campaign of mass action, therefore, would be different from democracy in Namibia, where independence from South Africa was won in 1990 through the efforts of different nationalist groups, including the South West African National Union (SWANU) and the South West Africa People's Organisation (SWAPO), who had been working towards their goal since the late 1950s (Saunders, 2009:439). 


\section{Nationalism}

The current MobiLex definition for nationalism similarly fails to encompass the changeable nature of the concept. The definition is:

1. The political belief that a group of people representing a national community sharing a language, culture, race and common history should live under one political system and be independent of others. 2. A devotion to the interests of one's own country. 3. A desire for national advancement. 4. The policy of asserting the interest of one's own nation, as separate from the interest of another nation and the common interest of all nations (MobiLex,http://www0.sun.ac.za/mobilex).

Writing on the topic of Afrikaner nationalism, Saul Dubow (1992:209) points out that this concept is one that also changes and is not rooted in a so-called "timeless tradition". Afrikaner nationalism was shaped to a large degree by the hardships endured, and defeat of the Afrikaners, in the South African War of 1899 to 1902 . The recovery process following this war led to Afrikaner nationalism attaining a racist dimension in that Afrikaners adopted ideas of racial superiority in an effort to rid themselves of the perceived defects of defeat at the hands of the British (Dubow, 1992:209-210). The historical forces that shaped Afrikaner nationalism contributed unique characteristics to it, in a way similar to how the social and linguistic nature of the Zulus lends unique qualities to Zulu nationalism.

The role of the Zulu king was crucial in uniting groups who shared the Zulu language. Following the disorienting experience of colonialism, this new sense of unity led to a form of nationalism that was markedly different from the nationalism that characterised the nation during the pre-colonial era, when the Zulus had not yet identified themselves as a distinctive ethnic group (Choi, 2008:43). Zulu nationalism continued to change and adapt as the political context altered (Harries, 1993:112-113). According to Bozzoli (1990:238), nationalist political and social movements have long employed self-serving interpretations of the past to strengthen and justify their existence. So while Apartheid forced Afrikaner and Zulu nationalism to opposite sides of the political spectrum, both of these groups used history, or more specifically myth, to advance a sense of nationalism.

However, while there are similarities in how these two groups interpret the past, Zulu nationalism and Afrikaner nationalism remain two concepts that cannot be subjected to one definition because of each one's unique historical context. Modern forms of democracy similarly cannot share a single definition. 


\section{National democracy and democratic nationalism}

While concepts of both nationalism and democracy emerged during antiquity, more recent examples from history illustrate the complexities of these terms. The so-called Year of Revolutions in Europe, 1848, brought about significant political and socio-economic changes that held both shortterm and long-term consequences.

Ideas on nationalism and democracy started to transform with the French Revolution of 1789, which overthrew the medieval Feudal system. In linking ideas of patriotism with citizenship, a form of democratic nationalism emerged. At the same time, another form of nationalism grew out of a greater emphasis on language and culture (Hahn, 2013:145). The manner in which countries such as France and Germany dealt with new ideas on nationalism, to a large extent determined the manner in which they interpreted democracy.

In France, for instance, the influence of the Enlightenment and the revolutionary notions of fraternity, equality and liberty steered ideas around nationalism towards an emancipatory goal by 1848 . As such, nationalism and liberty became associated with one another as concepts that would bring about positive change. The French did not limit these ideas to France and the French Minister of Foreign Affairs in 1848 stated that his country would help people elsewhere who were striving towards national freedom (Kumar, 2015:596).

In Germany, however, nationalism and liberty were seen as opposing mind-sets and when the Germans became a unified nation in 1871 , it was at the expense of liberal ideas, bringing about a form of government that lent authoritarian powers to the Kaiser (Berghahn, 2005:178). Individual freedom, which was central to French Revolutionary ideas, was certainly not the goal in Germany during the era of unification. Georg Wilhelm Friedrich Hegel, a German philosopher, is widely regarded as the "intellectual and spiritual father of German nationalism” (Avineri, 1962:463). However, from Hegel's personal correspondence it was clear that he was a opponent to German unification, expressing relief when the Congress of Vienna put a temporary stop to it in 1815 (Avineri, 1962:462). Hegel did, however, also believe that personal liberty was of lesser importance than the needs of the wider community. By supporting this view of Hegel's idea of personal freedom, supporters of Conservatism were able to oppose radical change of the state (Perry, 1997:373). 
So, while both Germany and France each experienced a sense of nationalism, the way they approached it resulted in different forms of government. Following the revolutions of 1789 and 1848, France emerged with a democratic government because the population played a role in the changes within the country. In Germany, in contrast, the changes were brought about primarily by those in power, leaving the people largely voiceless (Berghahn, 2005:178).

\section{Finding online lexicographical resources for students in History}

When compiling a LSP dictionary like MobiLex, it is common practice to consult subject experts in History Education, but also to consult established reference works on History, including LSP dictionaries. Theoretically speaking, one would expect the lexicographical resource for finding conceptual information on the terms democracy and nationalism to be a LSP dictionary of historical terms and online dictionaries of historical terms were also consulted in the search for a solution to the problem. It seemed that electronic resources for dictionaries of history are almost impossible to find, as a university library search found no such resources for a LSP dictionary of terminology for history. A quick search in A Dictionary of World History, Oxford Online version 2015 clearly indicated why the user would not find explanations or definitions of the two concepts, as this dictionary functions more like an encyclopaedia. See the introduction below:

This wide-ranging dictionary contains a wealth of information on all aspects of history, from prehistory right up to the present day. It includes biographies of key figures in world history, historical summaries for each country and entries on political and religious movements, international organizations, and key battles and places (Kerr \& Wright, 2015, Dictionary of World History).

Gouws and Prinsloo (2005:48) distinguish between encyclopaedic and linguistic dictionaries as follows: encyclopaedic dictionaries, often also known as encyclopaedias, are directed at the extra-linguistic features of the items to be treated whereas linguistic dictionaries focus on the linguistic and pragmatic aspects. According to this distinction made by the authors, it would appear that A Dictionary of World History (Kerr \& Wright, 2015) functions as an encyclopaedia and should rather have been called an encyclopaedia, as the focus is on extra-linguistic information and not linguistic information at all. It does not even function as an encyclopaedic dictionary, as no linguistic information on historical terms is supplied.

A further university library search for the concepts democracy and nationalism turned out to be less successful. Although the concepts were found in 
Pharos dictionaries (a well-known South African dictionary publisher of LSP dictionaries), the results in this case did not pertain to subject matter and descriptions of an academic nature, but only conveyed the general meaning of the term, as well as translations. Strangely enough, the search for democracy in Pharos online obtained 40 results, while the search for the Afrikaans equivalent demokrasie in Pharos online found 46 results.

A search for democracy at the University's Language Centre Terminology turned out to be successful, as the term is included in two glossaries. It is clear, however, that the definitions below do not provide an adequate academic description of the concept, but rather generalise the concept. As could be gathered from the titles of the glossaries, the target users are not students of history, but students of sociology and public and development management:

Democracy system of government based on the principle of representing all people through the right to vote (List for sociology terms, University of Stellenbosch, Langauge Centre).

Democracy government of the people by the people, usually through their elected representatives. In our case it means government by the majority through votes (List for public and development management terms, University of Stellenbosch, Langauge Centre).

Assistance in the meaning of the concepts of nationalism and democracy comes from an unexpected source, namely the comprehensive dictionary of Afrikaans, the Woordeboek van die Afrikaanse Taal (WAT), 2003 available online. According to Gouws and Prinsloo (2005:49), comprehensive dictionaries have an overall-descriptive and informative approach and give an account of the full spectrum of the lexicon. Comprehensive dictionaries are typically historically oriented and are directed at lexicographic treatment of the past and present characteristics of the language. A chronological indication of the development of the form and meaning of a lexical item is given, and its origin and etymology is described. It is therefore not unusual that a very good description of the term demokrasie is found in the WAT, as well as a reliable account of the use of nasionalisme, especially in the sources cited in the dictionary, as is seen in the excerpts that follow. The citations in the WAT reflect the use of nasionalisme in a balanced way, making provision for different perspectives on nationalism in the South African context.

Demokrasie s.nw.

a Regeringsvorm waarin die hoogste gesag by die volk berus en uitgeoefen word (1) direk (absolute of direkte demokrasie, soos gedeeltelik toegepas in enkele Switserse kantons), of (2) indirek deur 'n stelsel van verteenwoordiging en gedelegeerde mag wat van tyd tot tyd 
deur middel van verkiesings verander kan word (indirekte demokrasie); regeringsvorm waarin alle klasse van die samelewing, selfs die laagste, 'n stem het, direk of deur hulle gekose verteenwoordigers; dit berus op die grondslag van gelykheid van almal sonder erflike of arbitrêre verskille wat stand of voorregte betref - teenoor aristokrasie of outokrasie; verder word as essensiële beginsels o.a. beskou 'n groot mate van persoonlike vryheid, "reg op jou lyf en goed", algemene en geheime kiesreg, openbaarheid van staatsbeleid (sover prakties moontlik), reg tot opposisie, die wil van die meerderheid as beslissende faktor, vryheid van die pers, ondergeskiktheid van militêre gesag aan burgerlike gesag, ens.; volksregering: Hoofgedagte van die demokrasie is dat die definitiewe seggingsmag oor die staatsbeleid by die volk, d.w.s. by die volk se gekose verteenwoordigers, berus. Verskillende volke besit verskillende soorte demokrasie in die sin van regeertegniek wat by hul aard of opvatting aangepas is. Demokrasie is die bestuursvorm waaraan' $n$ groot aantal lede van die gemeenskap direk of indirek deelneem en waar die geestelike vryheid en gelykheid voor die wet gewaarborg is. Demokrasie is die sosiale orde waarin die beginsels op grond waarvan gesag uitgeoefen word, bepaal word deur hulle wat aan hierdie gesag onderwerp is en die uitoefening daarvan deur of namens hulle gekontroleer word (J. Bierens de Haan). Ekonomiese demokrasie - sien EKONOMIES, 2.

b mv. demokrasieë. Staat of gemeenskap wat so geregeer word: Die Unie van S.A. is ' $n$ demokrasie.

Vgl. VOLKSDEMOKRASIE.

Nasionalisme s.nw. (met mv. in bet. 2)

1 Gedagtesisteem, politieke beskouing of ideologie waarby die gemeenskaplike aspirasies, belange, kenmerke en waardes v.d. nasie (NASIE 1) eerste gestel word ten einde ' $n$ bep. onderskeidende nasionale identiteit te verkry of te vestig, gekenmerk deur' $n$ liefde vir en verheerliking van die eie nasie, en i.d. geval van niesoewereine nasies, gemanifesteer in 'n strewe na nasionale selfstandigheid en politieke onafhanklikheid: Die begeerte van die mense om vry en onafhanklik te word (m.a.w. die opkoms van nasionalisme) (het) baie te doen gehad met die verswakking van die Weste se invloed (AJ van Rensburg in Afr. Kinderens. XI, 1962, 4869). Die volkere van die Ooste en van Afrika vertoon in stuwende nasionalisme, in groeiende drang om hulself te laat geld (S.J. Preller: Gemeenskap, 1960, 13). Die verbrokkeling van die Ottomaanse ryk het nasionalisme in die nuwe Islamstate laat ontwaak (ANJ Herholdt: N Afrika, 1970, 3).

$2 \mathrm{mv}$. Nasionalismes. Gedagtesisteem, politieke lewensbeskouing of ideologie van in bep. groep, bv. 'n bevolkingsgroep, etniese groep e.d., waarby die gemeenskaplike aspirasies, belange, kenmerke en waardes v.d. groep binne' $n$ bep. geografiese gebied gehandhaaf word m.d. doel om afsonderlikheid of uniekheid v.d. groep te bevorder, dikw. ter verkryging of vestiging v.d. groep se onafhanklikheid: Bruin, ekonomiese, kommunistiese, Oosterse, swart, wit nasionalisme. $\approx$ Elke bevolkingsgroep het in hegte eenheid gevorm wat deur sy eie nasionalisme saamgebind was - eie taal, eie kultuur, eie tradisie, ... met trou aan eie volk (U Jooste: Goud II, 1975, 128). Wanneer in mens nasionalismes vergelyk, is die groot moeilikheid dat elke nasionalisme ... uniek is... In die Afrikaanse en die Joodse nasionalisme moet in mens geïmponeer wees deur die sentrale rol van ... die eie kulturele lewe (Buurman, Desember 1970, 4) (Woordeboek van die Afrikaanse Taal, 2003). 
Another source consulted by the researchers was The Dictionary of South African English (DSAE) (Silva, 2010), another comprehensive dictionary. The DSAE does not include the terms democracy and nationalism, but the term nationalist could be found in the dictionary. Although a sufficient and comprehensive definition of the concept is not supplied, citations in chronological order ranging from 1911 to 1993 could be found. These citations demonstrate a onesided definition of the term nationalist, though, by only referring to the case of the Nationalist Party and not encompassing a balanced view of the term used in the South African context. Please refer below:

Nationalist $n$. and adj. Also occas. with small initial.

Origin: tr. Afk. Nasionalis a member of the Nasionale Party the National Party.

A. $n$.

a. A member of any of the successive (predominantly Afrikaner) National Parties; in pl., a collective name for the National Party or its government; Nat n. sense a; NP sense 2 .

1911 Farmer's Weekly 4 Oct. 115 The good party man, whether he be Nationalist or Unionist whose political attitude is one of humble worship and genuflection.

1919 Illust. London News (U.K.) 6 June The Natives..kept loyal under strong temptation to make trouble for the Government from the Nationalists and proGerman Europeans.

1921 E. Prov. Herald 16 Feb. General Smuts will out-face the Nationalists with a nationalism bigger, broader, prouder and more inspiring than their own.

1933 Star 2 May 5 Mr Vorster said... he was still a Nationalist, but now supported General Smuts as strongly as any S.A.P. man.

1950 H. Gibbs Twilight in S. Afr. 237 The Nationalists' anti-Semitism in the 1930 sannot be ignored, neither can Dr. Malan's attempt to ban Jewish refugees in 1937 as prohibited immigrants.

1953 A.J. Luthuli in Drum May 11 As the Nationalists themselves have said, the laws which we oppose were not passed by them alone.

1964 M. Benson Afr. Patriots 211 The A.N.C. still hoped they (sc. the United Party) might learn they could never return to power by trying to beat the nationalists at their own game.

1973 Sunday Times 27 May 17 No Opposition group managed to break the increasing grip of the Nationalists on the 80 per cent or so of the Afrikaners who vote for them.

1979 T. Pakenham Boer War (1982) 576 The party founded by Botha and Smuts had been replaced in 1948 by Malan and the Nationalists.

1984 Frontline Mar. 39 Most English-speaking readers are easily [able] to remember the days when 'Nationalist' was virtually a synonym for 'Afrikaner'... English-speaking Nationalists were as rare as kudu in Eloff street.

1991 Sunday Times 10 Feb. 20 Like Alan Paton's Liberal Party, the Nationalists now put forward the vision of a non-racial South Africa..as the only viable alternative to the revolutionary socialist vision of the ANC and its communist pilot fish. 
1993 K. Owen in Sunday Times 7 Nov. 22 The Nationalists who destroyed South Africa's provincial system when it showed some timid independence from central government are now demanding a full-fledged federation (Silva, 2010).

The results from both above-mentioned lexicographical resources could possibly mislead researchers and compilers of MobiLex. The question remains however, whether a student of history would consider the WAT and the DSAE as possible reference sources to find conceptual information on history terms as they are not LSP dictionaries and it may be co-incidental that both these terms are in the dictionary.

In the online environment many university students rely on a Google search for the explanation of a term, therefore a Google search on the term nationalism was performed. A timeline illustrating the use of the term in the form of a graph was found, as indicated below. Such a graph is meaningless, as the research paradigm is not described to the user. No context is provided for the use of the term and students as well as researchers should be critical of such information. More information is needed as to when the data were collected, which data were collected and how data were collected.

\section{A Google search for the explanation of a term nationalism}

\section{Nationalism}

Use over time for: Nationalism

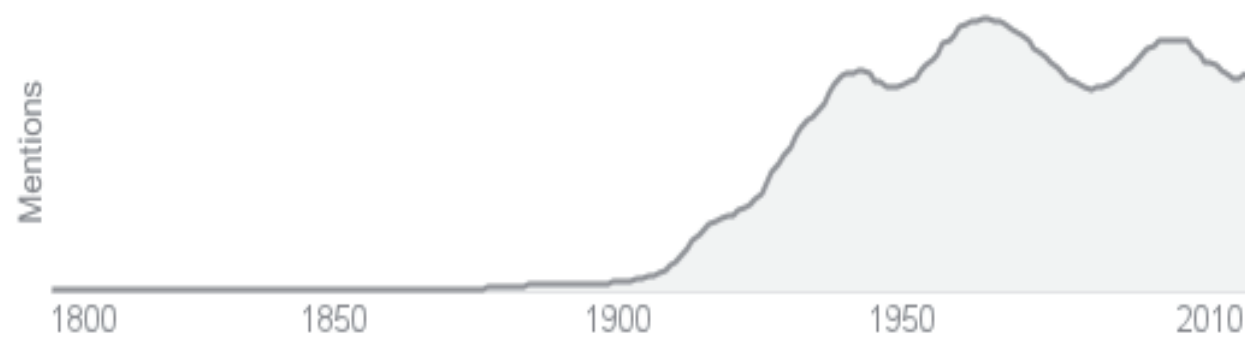

Source: Available at https://www.google.co.za/search?source=hp\&ei=pq4oW68kxZjoBKm4tEg\&q=na tionalism\&oq=nationalism\&gs_l=psy-ab. Accessed on 12 February 2018.

Searches related to definition of nationalism

- $\quad$ nationalism definition history

- what is nationalism in history

- nationalism examples

- nationalism vs patriotism

- types of nationalism

- nationalism in a sentence 
- nationalism synonym

\section{- define patriotism}

Search strings like the above could provide students and researchers with contextual clues for possible search actions in order to find the appropriate meaning or use of a term. Once again, however, the criteria for data collection are not mentioned and users cannot be sure of how reliable the data may be.

Adaptions to mobile LSP lexicography within a pedagogical framework for the implementation of technology in teaching are suggested in the next section.

\section{Lexicographical support for mobile History concepts within in a mobile environment}

According to Fuertes-Olivera (2011:96), specialised reference works must offer data for disambiguating the meaning and use of LSP terms in specific situations, typically in cognitive-oriented and communicative-oriented situations. This means (Fuertes-Olivera, 2011:96) that LSP dictionaries should be all-inclusive, i.e. a type of dictionary that adds conceptual data to the linguistic data normally provided. Tarp (2005:8) describes the pedagogical dimension of LSP dictionaries as follows:

The pedagogical value of a dictionary is thus determined by its appropriateness to provide either linguistic or encyclopaedic knowledge, or both, to the users during the process of linguistic or encyclopaedic learning. Consequently, if the pedagogical value of a specialized dictionary is determined by its appropriateness to provide LSP and/or specialized encyclopaedic knowledge, then every dictionary which contains data representing true knowledge may, up to a certain point, display a pedagogical dimension, although only the dictionaries designed for this specific purpose would be of any real benefit to the users interested in assimilating specialized linguistic and encyclopaedic knowledge.

MobiLex certainly displays a pedagogical dimension, as the purpose of the dictionary is to provide university students with conceptual, specialised and even encyclopaedic knowledge in a cognitive-oriented situation. It also provides linguistic knowledge on the translation of terms in at least two other South African languages in a communicative-oriented situation.

Bergenholtz, Nielsen and Tarp (2009:9) claim that the appearance of electronic dictionaries support function-based lexicographic theories that are centred on dictionaries and their users, with the aim to generate dictionaries based on functions needing to be fulfilled. Bergenholtz and Bothma $(2011: 60,61)$ describe various e-information tools and come to the conclusion that paper-based products are not feasible for fulfilling the various information needs of users and that modern 
information technologies are becoming more feasible for addressing those user needs. MobiLex uses mobile technology and could thus be viewed as a product using modern information technology to fulfil the needs of its target users. The demand for more encyclopaedic knowledge on terms of History to accommodate users could be met by making use of technology.

The Substitution Augmentation Modification Redefinition (SAMR) model, a model for evaluating integration of technology in teaching is applied to come up with a plausible solution to the problem that is posed. It could have the potential to change the face of language learning and language support for home language speakers, as well as additional language speakers. With the integration of technology in lexicography it would also be possible to make provision for adding conceptual knowledge to LSP dictionaries to fulfil the necessary information needs of users.

The SAMR model developed by Ruben Puentedura (2015) offers a method for seeing how computer technology might impact teaching and learning. It also shows a progression that adopters of educational technology often follow as they progress through teaching and learning with technology. On the first level, namely the one of substitution, it would mean replacement of paper by technology and, if applied to lexicography, it would mean having an electronic dictionary with no added features. On the second level, namely the one of augmentation, it would mean that technology acts as a direct tool substitute with functional improvement; if applied to lexicography, it could mean that a user could search for a word electronically without making use of alphabetical ordering to search for a word.

On the third level, namely the one of modification, technology allows for significant task redesign and, if applied to lexicography, it could mean that a user could search for a word by making use of intelligent predictions of the correct spelling of a word.

On the fourth and highest level, namely the one of redefinition, technology allows for the creation of new tasks previously inconceivable. If applied to lexicography it could entail the use of an interactive language game on the dictionary site to ensure user involvement. The success of the SAMR model lies in the fact that adequate technological features are utilized to ensure maximum user engagement in the process. Suggestions regarding better possible engagement of users with MobiLex are made in the conclusion. 


\section{Conclusion}

By analysing the historical context of two substantive concepts, nationalism and democracy, it is clear that the historical meaning is complex and nuanced. Not the historical period only, but also the geographical location of historical events influence the interpretation of the concepts. As such, it is clear that a single definition for any substantive concept is insufficient as it does not convey the historical meaning effectively.

Due to the nature of technology, the possibilities of MobiLex improving and expanding with time is likely. Some of these improvements may include supplying more and appropriate context by adding links to more extensive definitions, adding podcasts and vodcasts to the application. Users could listen to a podcast of a subject expert, for example a history lecturer, providing a thorough explanation of the concept of democracy in students' home language, whether Afrikaans, English or isiXhosa.

Podcasts could be added of a history lecturer explaining a substantive concept such as democracy or nationalism in students' home language in detail, whether Afrikaans, English or isiXhosa, with the aid of a world map to show the different interpretations of the specific substantive concept. In addition, the explanation of the concept should include historical context for the student to realise that the meaning of the concept may change as a result of historical time and geographical space.

Better user engagement would be ensured by better use of the potential of technology and using creative ways for students to be involved in the dictionary. A creative and new way of student involvement could entail students working collaboratively on a dictionary of History by compiling a dictionary in wiki format. Another possibility could be to design an interactive dictionary game concerning conceptual and linguistic knowledge, with reference to terms, their translations and definitions.

Due to the nature of many historical terms, as argued in the article, LSP dictionaries of History with rather lengthy definitions including encyclopaedic elements are needed to provide sufficient context in cognitive user situations. Citations also have an important role to play in creating context for the user. In all, it is clear that the format of traditional dictionaries is insufficient to provide a nuanced explanation of complex substantive concepts. As such, mobile dictionaries hold potential for greater scope in improving historical understanding of terms and concepts. 


\section{References}

Alberts, M 2017. Terminology and terminography principles and practice. Milnerton: McGillivray Linnegar.

Avineri, S 1962. Hegel and Nationalism. The Review of Politics, 24(4):461-484.

Bergenholtz, H \& Bothma, TJD 2011. Needs-adapted data presentation in e-information tools. Lexikos, 21:53-77.

Bergenholtz, H, Nielsen, S \& Tarp, S (Eds). 2009. Lexicography at a crossroad: Dictionaries and encyclopedias today, lexicographica tools tomorrow. Bern/Berlin/Brussels: Pieter Lang.

Berghahn, VR 2005. Imperial Germany 1871-1918: Economy, society, culture and politics. New York: Berghahn Books.

Bozzoli, B 1990. Intellectuals, audiences and histories: South African experiences, 19781988. Radical History Review, 46(7):237-263.

Choi, J 2008. The political origins of Zulu violence during the 1994 democratic transition of South Africa. Journal of International and Area Studies, 15(2):41-54.

Coffin, C 2006. Historical discourse. New York: Continuum.

Connor, WR 2018. Pericles on democracy: Thucydides 2.37.1. Classical World, 111(2):165-175.

Department of Basic Education, 2011. National Curriculum Statement (NCS), Curriculum and Assessment Policy Statement (CAPS). History: Further Education Phase (FET).

Donnelly, M \& Norton, C 2011. Doing History. Oxon: Routledge.

Dubow, S 1992. Afrikaner nationalism, apartheid and the conceptualization of 'race'. The Journal of African History, 33(2):209-237.

Fuertes-Olivera, P 2011. Equivalent selection in specialized e-lexicography: A case study with Spanish accounting terms. Lexikos, 21:95-119.

Gouws, RH \& Prinsloo, DJ 2005. Principles and practice of South African Lexicography. Stellenbosch: Sun Media.

Hahn, HJ 2013. The 1848 revolutions in German-speaking Europe. London: Routledge.

Harries, P 1993. Imagery, symbolism and tradition in a South African Bantustan: Mangosuthu Buthelezi, Inkatha, and Zulu history. History and Theory, 32(4):105-125.

Hobsbawn, E 2012. Nations and Nationalism since 1780: Programme, myth, reality, 2. Cambridge: Cambridge University Press.

Kerr, A \& Wright, E 2015. A Dictionary of World History, 3. United Kingdom: Oxford University Press. Available at https:/global.oup.com/academic/product/adictionary-of-world-history. Accessed on 5 February 2018.

Kumar, K 2015. Nationalism and revolution: Friends or foes? Nations and Nationalism, 21(4):589-608. 
Lévesque, S 2008. Thinking historically: Educating students for the twenty-first century. Toronto: University of Toronto Press.

Neumann, D 2012. Training teachers to think historically: Applying recent research to professional development. The History Teacher, 45(3):383-403.

Owusu, M 1992. Democracy and Africa - A view from the village. The Journal of Modern African Studies, 30(3):369-396.

Perry, M 1997. Western Civilization A Brief History. Boston: Houghton Mifflin Company.

Puentedura, R 2015.The SAMR model. Available at http://www.hippasus.com. Accessed on 5 February 2018.

Punch, KF \& A Oancea. 2014. Introduction to research methods in education. London: Sage.

Saunders, C 2009. Namibian solidarity: British support for Namibian independence. Journal of Southern African Studies, 35(2):437-454.

Silva, P (ed.) 2010. A Dictionary of South African English. Michigan: Oxford University Press. Available at dsae.co.za. Accessed on 5 February 2018.

Tarp, S 2005. The pedagogical dimension of the well-conceived specialized dictionary. Iberica, 10:7-21.

University of Stellenbosch. n.d. MobiLex. Available at http://www0.sun.ac.za/mobilex. Accessed 5 February 2018.

Williams, G 2003. Democracy as idea and democracy as process in Africa. The Journal of African American History, 88(4):339-360.

Woordeboek van die Afrikaanse Taal, 2003. Available at http://www.wat.co.za. Accessed on 5 February 2018. 